\title{
Study and Analysis of Shading Effects on Photovoltaic Application System
}

\author{
Handoko Rusiana Iskandar $^{1, \mathrm{a}}$, Yuda Bakti Zainal $^{1}$ and Susanto Sambasri ${ }^{1}$ \\ ${ }^{I}$ Electrical Engineering, University of Jenderal Achmad Yani, Cimahi, Indonesia
}

\begin{abstract}
This study investigates the shading on PV systems. Shading has considerable influence on the solar cells characteristics, temperature and radiation on site need to be considered as the basis for designing PV systems. Modeling conducted on a $1 \mathrm{kWp}$ PV system at a latitude of $6^{\circ} 53^{\prime 2} .69^{\prime \prime} \mathrm{S}$ and a longitude of $107^{\circ} 32^{\prime} 28.69^{\prime \prime}$, to find the magnitude of solar radiation, surface temperature, and tilt angle, and partial shadow simulation using PVsyst software. Testing result shows the characteristic PV $1 \mathrm{kWp}$ is obtained with the angle of solar cell shade at $18^{\circ}$ and azimuth $0^{\circ}$, the shading per year generates $4.71 \mathrm{kWh} / \mathrm{m}^{2}$ in a solar active area at $6.9 \mathrm{~m}^{2}$, the power losses of $20.8 \%$ of its nominal power.
\end{abstract}

\section{Introduction}

\subsection{Background}

The global issue of reduced fuel oil resources encourages human beings to play a role in the expansion of the utilization of renewable energy sources such as Photovoltaic Systems [12]. The PV system has an important role as a source of one of environmentally friendly renewable energy. The PV system has been widely used in various public facilities. To design a PV system some testing must be done, i.e the characteristics of solar panels. These characteristics will affect the maximum working of the PV. Optimum characteristics of solar cells in terms of cell material and panel. They are closely related to the surrounding conditions, both of the solar irradiance, surface temperature, tilt angle, and shade. The shading effect will be modeled to find the loss of the PV output and the tilt angle match.

The characteristics of solar cells are seen from the parameters in the $\left(I_{S C}\right)$ curve with $\left(V_{O C}\right)$ and several other factors affecting the characteristics of solar cells are the rise and fall of temperature and solar irradiance, as well as the effect of shading, were adopted from $[3,4]$. Several related studies linked with percentage efficiency of solar panels [1], combining the effect of temperature and solar intensity on the power of solar panels used simulated [2]. Another influence is the deterioration of power caused by the placement of panels in the shade, the results of these experiments show an accuracy increase of $5-10 \%$ which is modeled by [3], another approach to the analysis of shading effects or losses caused by[4], partial shading was done by the investigation conducted using Matlab to show an increase. Other methods ANN used to detect errors occurring on or the PV module

\footnotetext{
${ }^{\text {a }}$ Corresponding authors: handoko.rusiana@lecture.unjani.ac.id
} 
is tested under normal partial shadow conditions. these inputs are randomly tested performed by [5][1]. Decreased power due to shading effect can be optimized using fuzzy logic by [6], this approach can increase the Maximum Power Point Tracker although the power characteristics of PV influenced shading effect [7-8]. It can be concluded that there are some losses to the solar cell power rating such as the decrease caused by the influence of irradiance and temperature, the effect of shading on the solar panel due to the environment condition. It is, therefore, necessary to have an optimal installation or slope study of solar panels, by reducing the effect of shading, irradiance and temperature accordingly.

\subsection{Location and Geographical}

In this research, $1 \mathrm{kWp}$ PV system will be applied in the Electrical Engineering Laboratory, University of Jenderal Achmad Yani, Cimahi, Indonesia. Based on NASA Surface Meteorology \& Solar Energy the location of this solar insolation is $4.81 \mathrm{kWh} / \mathrm{m}^{2} /$ day, wind speed $3.81 \mathrm{~m} / \mathrm{s}$ and average air temperature $27.0^{\circ} \mathrm{C}$ and humidity $81.9 \%$ per year at a latitude of $6^{\circ} 53^{\prime} 2.69^{\prime \prime} \mathrm{S}$ and a longitude of $107^{\circ} 32^{\prime} 28.69^{\prime \prime} \mathrm{E}$ or -6.884082 and 107.541304 .

Table 1. Monthly meteo data

\begin{tabular}{|c|c|c|c|c|c|}
\hline \multirow[b]{2}{*}{ Month } & \multicolumn{3}{|c|}{ At tilt angle $18^{\circ}$ and azimuth $0^{\circ}$} & \multirow[b]{2}{*}{$\begin{array}{c}\text { Temperature } \\
\left({ }^{\circ} \mathrm{C}\right)\end{array}$} & \multirow[b]{2}{*}{$\begin{array}{l}\text { Wind } \\
\text { Velocity } \\
(\mathrm{m} / \mathrm{s})\end{array}$} \\
\hline & $\begin{array}{c}\text { Global } \\
\text { Irradiance } \\
\left(\mathrm{kWh} / \mathrm{m}^{2} . \text { day }\right)\end{array}$ & $\begin{array}{c}\text { Tilt Global } \\
\left(\mathrm{kWh} / \mathrm{m}^{2} \text {.day) }\right.\end{array}$ & $\begin{array}{l}\text { Shed Global } \\
\left(\mathrm{kWh} / \mathrm{m}^{2} \text {.day }\right)\end{array}$ & & \\
\hline Jan & 4.18 & 4.59 & 4.55 & 26.0 & 3.31 \\
\hline Feb & 4.25 & 4.46 & 4.42 & 25.9 & 3.333 \\
\hline Mar & 4.76 & 4.75 & 4.71 & 26.5 & 2.66 \\
\hline Apr & 4.82 & 4.53 & 4.49 & 27.2 & 3.02 \\
\hline May & 4.74 & 4.24 & 4.20 & 27.8 & 3.97 \\
\hline Jun & 4.58 & 4.00 & 3.96 & 27.8 & 4.34 \\
\hline Jul & 4.86 & 4.26 & 4.22 & 27.5 & 5.29 \\
\hline Aug & 5.24 & 4.78 & 4.74 & 27.5 & 5.38 \\
\hline Sep & 5.56 & 5.41 & 5.36 & 27.4 & 4.93 \\
\hline Oct & 5.32 & 5.52 & 5.48 & 26.9 & 3.71 \\
\hline Nov & 4.80 & 5.26 & 5.21 & 26.6 & 3.09 \\
\hline Des & 4.63 & 5.22 & 5.18 & 26.3 & 2.69 \\
\hline Average/year & 4.81 & 4.75 & 4.71 & 2.69 & 3.8 \\
\hline
\end{tabular}

\section{Modeling of photovoltaic systems}

\subsection{Photovoltaic characteristics}

According to [9]. solar cells consisting of a row of panels, the shadow effect will reduce the output power is generally there are two things, the first is during the winter season in northern latitudes and the second if the available area of the system is limited. Leading to a very small spacing between the rows. Other parameters are characteristic of the solar cell at current-voltage, among other, $I_{S C}, V_{O C}$, maximum power also fill factor. Solar cells can be modeled as current sources paralleled with diodes based on Schockley diodes. By using the source of solar radiation it is obtained the characteristics when compared with the modeling results then the difference and similarity will be any further analysis, the factors that affect these characteristics is the level of solar radiation and temperature in solar cells[1-5,-10$11]$. 
$i_{p v}=i_{p h}-i_{o}\left[\exp \left(\frac{v_{p v}+i_{p v} R_{S}}{n k_{B} T / q}\right)-1\right]-\frac{v_{p v}+i_{p v} R_{S}}{R_{p}}$

This junction absorbs photon energy from sunlight and generates electron-hole pairs that propagate throughout the junction so as to produce an electric field passing through the junction and causing an electric current flow. Equation (1) shows $I_{P V}$ and $V_{P h}$ is the current and output voltage of the PV cell, $I_{P h}$ is the current generated from the photon energy absorption process.

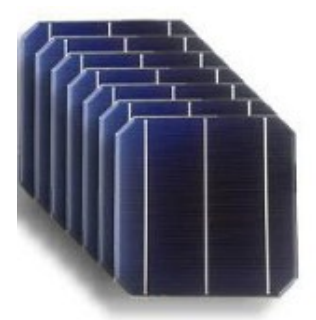

(a)

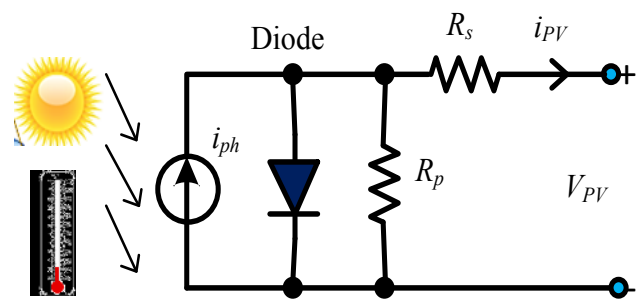

(b)

Fig. 1. Solar cell; a) physical model, b) equivalent circuit of a solar cell

Figure 1 shows the standard equivalent circuit for solar cells is a circuit model consisting of 1 diode, a constant source for photo-generated current $\left(i_{o}\right)$, series resistance $\left(R_{S}\right)$ and parallel constraints $\left(R_{s h}\right)$ [12]. The calculation of the voltage and current of the PV system depends on the configuration. The value $V_{m p_{-} n}$ and $I_{m p_{-} n}$ each solar module can be obtained from the data provided by the manufacturer.

Table 2. Mechanical data of solar cell

\begin{tabular}{|c|c|}
\hline Module & Cells \\
\hline Length $1.23 \mathrm{~m}$ & Si-mono \\
\hline Width $0.56 \mathrm{~m}$ & 1 in parallel \\
\hline Thickness $350 \mathrm{~mm}$ & 36 in series \\
\hline Weight $6.50 \mathrm{~kg}$ & Cell area $191 \mathrm{~cm}^{2}$ \\
\hline
\end{tabular}

Model through given Isc, Mpp, Voc

Incident Irrad. $=1000 \mathrm{~W} / \mathrm{m} 2$, Cells temp. $=25^{\circ} \mathrm{C}$
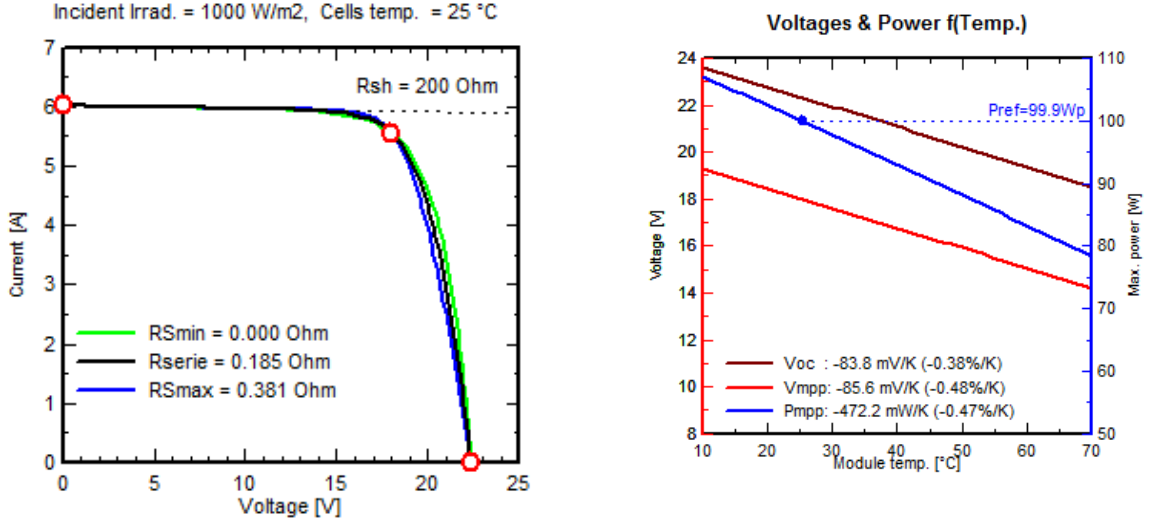

(a)

(b)

Fig. 2. Simulation of cell characteristics; a) I-V curve, b) temperature coefficient setting 
This photon current is proportional to the solar radiation level of the sun. While $i_{0}$ is the diode saturation current, which shows the diode characteristics. $q$ is the charge of the electron, and $n$ is an ideal factor, $\mathrm{k}$. B is Boltzman's constant, then T is the temperature of the PV cell in Kelvin, $R_{p}$ is the shunt resistance associated with the leakage current of the cell through the junction to the inside of the cell. Furthermore, $R_{S}$ is a series resistance showing the losses of the circuit interconnection, the other two important parameters in the characteristic PV cell are $I_{S C}$ and $V_{O C}$. Figure 2 shows the I-V curve and power and voltages under module temperature $\left({ }^{\circ} \mathrm{C}\right)$.

\subsection{Configuration of PV systems}

Total operating voltage and current calculations depend on the configuration of installed solar modules in series, parallel, or series-parallel [13]. Series have given by equation (3), (4).

$$
V m p_{\text {total-series }}=\sum_{n}^{i}=1 V m p_{-} n
$$

$$
\operatorname{Im} p_{\text {total }- \text { series }}=\operatorname{Imp} \_n
$$

The type of solar cell used is silicone mono-crystalline, with open land installation mode. The value $V_{m p_{n}}$ and $I_{m p_{-} n}$ each solar module can be obtained from the data provided by the manufacturer. Specification and calculation result gave by table 3 . Optimum operating voltage $\left(V_{m p}\right) 18$ Volts, an open circuit voltage $\left(V_{O C}\right)$ is $223.6 \mathrm{~V}$ and the sum of voltage for 10 solar panels of $180 \mathrm{~V}$. The temperature relationship take effect on the temperature drop in the solar panel, determination of the temperature dropping factor given by equation (5),

$$
f_{\text {temp. }}=1-\gamma\left(\text { Tcell }_{\text {eff }}-T_{S T C}\right)
$$

Definition of $\gamma$ is air temperature coefficient in $\left(\% /{ }^{\circ} \mathrm{C}\right), \operatorname{Tcell}_{e f f} \mathrm{PV}$ cell temperature in average and $T_{S T C}$ is the standard test condition temperature in $1 \mathrm{~kW} / \mathrm{m}^{2}$ at $25^{\circ} \mathrm{C}$. Figure 3 (a) and (b) similarly shows the I-V curve with variant irradiance to give the Maximum Power Point at the PV system. This simulation using table 3 for calculation.

Table 3. PV module manufacturer specification

\begin{tabular}{|c|c|}
\hline Parameters & Information \\
\hline Brands and Type & SUMICO TN-100M \\
\hline Maximum power $\left(P_{\max }\right)$ & 1008 Watt peak \\
\hline Max. operating current $\left(I_{\left.\operatorname{mp} p_{\max }\right)}\right)$ & 5.56 Ampere \\
\hline Short Circuit Current $\left(I_{S C}\right)$ & 6.02 Volt \\
\hline Temp. The coefficient of $P_{\max }(\%)$ & $-0.47 /{ }^{\circ} \mathrm{C}$ \\
\hline
\end{tabular}




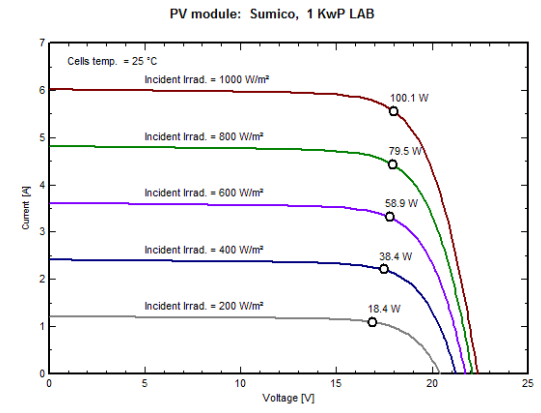

(a)

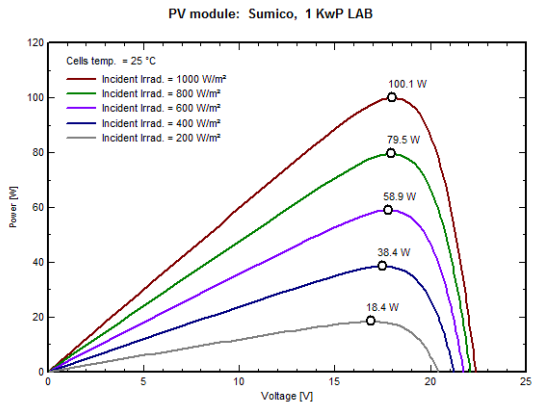

(b)

Fig. 3. Simulation result; a) I-V curve according to irradiance $\left(\mathrm{W} / \mathrm{m}^{2}\right)$, b) P-V curve according to temperature $\left({ }^{\circ} \mathrm{C}\right)$

\subsection{Shading calculation}

Depending on the position of the Sun, a single line of panels may be partial or all will be shaded. The shading effect is a change in the current-voltage characteristics (I-V) of the system, and consequently a reduction in the power output. For certain shadows in the system, the optimum tilt is generally not the same and will be different.

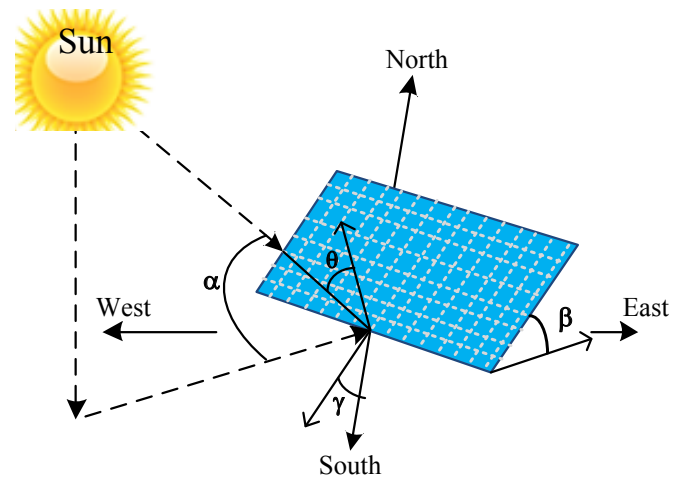

Tilt $18^{\circ}$

Azimuth $0^{\circ}$
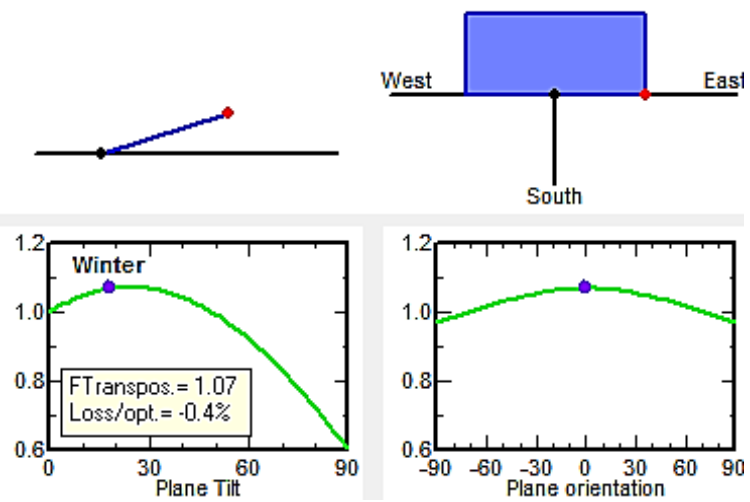

(a)

Fig. 4. Definition; a) angle on PV panel, b) simulation 
The construction of PV system the result of shaded areas per total area involving other electrical losses[8]. We have to define the sun position given by time function, latitude and longitude and then used to calculate the size and position of the shading area. The altitude $\alpha$ of the Sun as a function of latitude $\phi$, solar declination $\delta$ and angle $\omega$ subtended by the sun at a particular hour is given by[9].

$$
\sin \alpha=\sin \phi \sin \delta+\cos \phi \cos \delta \cos \omega
$$

The angle $\theta$ from the direction of the solar radiation beam on the sloping surface of PV cell is following equation (6),

$\cos \theta=$

$\cos \delta \cos \omega(\cos \gamma \sin \beta \sin \phi+\cos \phi \cos \beta)+\sin \delta(\sin \phi \cos \beta-\cos \gamma \cos \phi \cos \beta)+$ $\sin \gamma \sin \beta \cos \delta \sin \omega$

For a south facing surface, $\gamma=0$ and equation (12) so that it becomes and shows by Figure 4, Where $\gamma$ is the azimuth angle and $\beta$ is the tilt of the surface azimuth.

$$
\cos \theta=\sin (\phi-\beta) \sin \delta+\cos (\phi-\beta) \cos \delta \cos \omega
$$

PVSyst. Software used for model and simulation. Figure 4 used to set the angle tilt solar panel, this a supporting application in analysis shading and dynamically simulating photovoltaic systems on the site [14]. Figure 5 is the simulation for a movement from the angle of the sun as it passes through the sky, we must know its height and azimuth. The altitude is the angular distance above the horizon measured perpendicular to the horizon. It has a maximum value of $90^{\circ}$ on the zenith, which is the dot above our head. Azimuth distance of the measured angle is seen in a clockwise direction. Other things to consider is Albedo, albedo is a reflection effect on the surface. This effect affects the amount of solar energy reflected back into space. Albedo on earth shows a decrease in temperature. Albedo values in some places will be different where dry albedo value will be less than cold or wet areas.

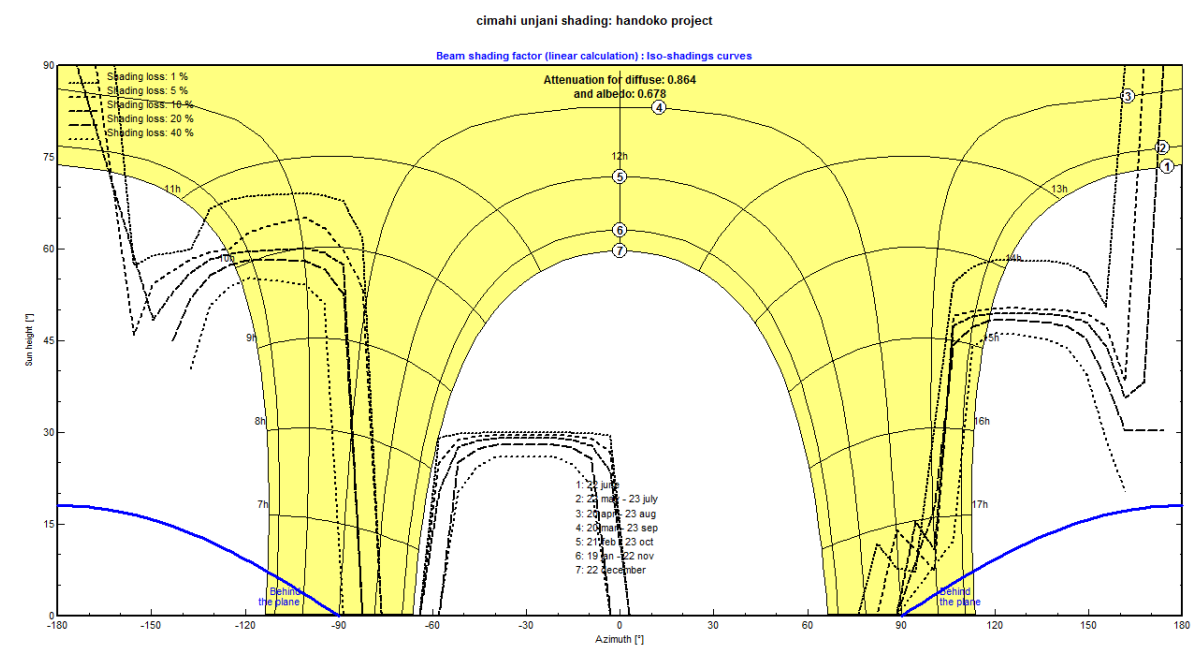

Fig. 5. Beam shading factor on linear condition 
Table 4. Shading factor table (linear), for the beam component.

\begin{tabular}{|l|l|l|l|l|l|l|l|l|l|l|l|l|l|l|l|l|l|l|l|}
\hline \multicolumn{1}{|c|}{ Azimuth } & $-180^{\circ}$ & $-160^{\circ}$ & $-140^{\circ}$ & $-120^{\circ}$ & $-100^{\circ}$ & $-80^{\circ}$ & $-60^{\circ}$ & $-40^{\circ}$ & $-20^{\circ}$ & $0^{\circ}$ & $20^{\circ}$ & $40^{\circ}$ & $60^{\circ}$ & $80^{\circ}$ & $100^{\circ}$ & $120^{\circ}$ & $140^{\circ}$ & $160^{\circ}$ & $180^{\circ}$ \\
Height & & & & & & & & & & & & & & & & & \\
\hline $90^{\circ}$ & 0.800 & 1.000 & 1.000 & 1.000 & 1.000 & 1.000 & 1.000 & 1.000 & 1.000 & 1.000 & 1.000 & 1.000 & 1.000 & 1.000 & 1.000 & 1.000 & 1.000 & 1.000 & 0.800 \\
$80^{\circ}$ & 0.791 & 1.000 & 1.000 & 1.000 & 1.000 & 1.000 & 1.000 & 1.000 & 1.000 & 1.000 & 1.000 & 1.000 & 1.000 & 1.000 & 1.000 & 1.000 & 1.000 & 1.000 & 0.800 \\
$70^{\circ}$ & 0.785 & 1.000 & 1.000 & 1.000 & 1.000 & 1.000 & 1.000 & 1.000 & 1.000 & 1.000 & 1.000 & 1.000 & 1.000 & 1.000 & 1.000 & 1.000 & 1.000 & 1.000 & 0.800 \\
$60^{\circ}$ & 0.776 & 1.000 & 1.000 & 0.934 & 0.898 & 1.000 & 1.000 & 1.000 & 1.000 & 1.000 & 1.000 & 1.000 & 1.000 & 1.000 & 1.000 & 1.000 & 1.000 & 1.000 & 0.800 \\
$50^{\circ}$ & 0.764 & 1.000 & 0.833 & 0.237 & 0.403 & 1.000 & 1.000 & 1.000 & 1.000 & 1.000 & 1.000 & 1.000 & 1.000 & 1.000 & 1.000 & 0.947 & 0.952 & 1.000 & 0.800 \\
$40^{\circ}$ & 0.741 & 1.000 & 0.686 & 0.000 & 0.226 & 1.000 & 1.000 & 1.000 & 1.000 & 1.000 & 1.000 & 1.000 & 1.000 & 1.000 & 1.000 & 0.000 & 0.269 & 1.000 & 0.800 \\
$30^{\circ}$ & 0.800 & 1.000 & 0.686 & 0.000 & 0.224 & 1.000 & 1.000 & 1.000 & 1.000 & 1.000 & 1.000 & 1.000 & 1.000 & 1.000 & 1.000 & 0.000 & 0.000 & 0.795 & 0.800 \\
$20^{\circ}$ & 0.800 & 1.000 & 0.686 & 0.000 & 0.224 & 1.000 & 1.000 & 0.000 & 0.000 & 1.000 & 1.000 & 1.000 & 1.000 & 1.000 & 0.793 & 0.000 & 0.000 & 0.576 & 0.800 \\
$10^{\circ}$ & 0.800 & 1.000 & 0.686 & 0.000 & 0.224 & 1.000 & 1.000 & 0.000 & 0.000 & 1.000 & 1.000 & 1.000 & 1.000 & 1.000 & 0.943 & 0.000 & 0.000 & 0.358 & 0.800 \\
$2^{\circ}$ & Behind & Behind & Behind & Behind & 0.224 & 1.000 & 1.000 & 0.000 & 0.000 & 1.000 & 1.000 & 1.000 & 1.000 & 1.000 & 1.092 & Behind & Behind & Behind & Behind \\
\hline
\end{tabular}

Partial shadings on 1 cells in one diode-group - for one string of 10 modules

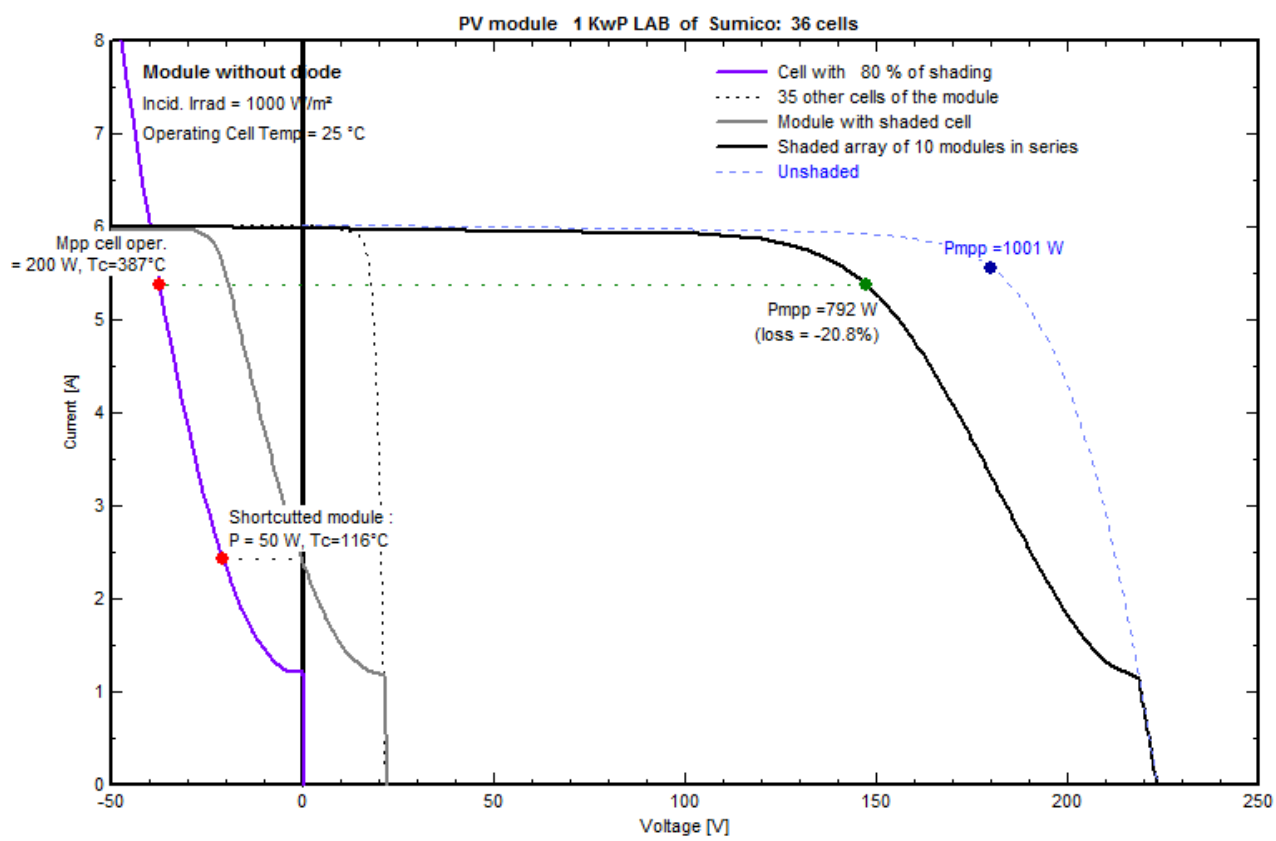

Fig. 6. $P_{\text {loss }}$ at $80 \%$ of shading on one module

Figure 6 visualizes the behavior of voltages and currents at the terminals of a shaded (or bad) cell, placed in a module or a group of modules. It evaluates the energy dissipation of this cell for various operating points, and its resultant temperature by making reasonable analysis for the thermal loss factor.

\section{Result and Discussion}

When the solar cell operates, one of the most important measurable values is the power. In contrast, the behavior of the current source is observed on the left side of the I-V curve. There is an operating point where the output power will be maximized. This point of operation is called Maximum Power Point (MPP). The PV system is required to always operate close to the point of MPP it is intended to obtain the energy gain in the maximum state. The linear current of the linear $I_{S C}$ depends on the degree of solar radiation whereas the $V_{O C}$ open-circuit voltage shows the dependence of the temperature present in the solar cell. $I_{S C}$, and $V_{O C}$ are measured under $T_{\text {reff }}$ are $25^{\circ} \mathrm{C}$, and irradiance $\lambda_{\text {reff }}$ in $1000 \mathrm{~W} / \mathrm{m}^{2}$, $T_{\text {reff }}$ and $\lambda_{\text {reff }}$. The value of $\operatorname{mu} P_{\text {max }}$ and $m u V_{O C}$ temperature coefficient are output one diode model which are dependent on the Gamma, in this simulation Gamma we put 1.30 
with Gamma coefficient temperature $-0.0007^{\circ} \mathrm{C}$. Diode saturation current, quality factor and voltage temperature coefficient determined by this requirement. According to the nameplate module, the solar panel temperature coefficient has $-0.47 \% /{ }^{\circ} \mathrm{C}$ at maximum power. Generally, silicone crystalline type modules have -0.4 to $-0.5 \% /{ }^{\circ} \mathrm{C}$ (see table 3 ) result of the simulation of the efficiency per cell area is $14.56 \%\left(6.880 \mathrm{~m}^{2}\right)$ and per module area is $0.15 \%\left(0.68 \mathrm{~m}^{2}\right)$.

Shading analysis performed on each cell, these specifications in one panel consisting of 36 cells tested with Irradiance $1 \mathrm{~kW} / \mathrm{m}^{2}$ and $T_{c} 25^{\circ} \mathrm{C}$. The other parameters, the losses are about $20.8 \%$, the $P_{m p p}$ value will decrease to $792 \mathrm{~W}$ of nominal power. This shows the phenomenological study of the resultant I-V characteristic of a module or PV array, composed of non-identical cells or modules shows the partial shading curve between currents and voltages on one module. Near shading simulation result from the showing a shading factor from the simulation of Electricity losses in PV systems are generated from shaded areas per total area. Table 4 describe the shading factor is a complex calculation which spends too much time to be performed during a simulation at each time step. Therefore the program builds a table in sun's height ( $10^{\circ}$ steps $)$ and azimuth $\left(20^{\circ}\right.$ steps $)$. The simulation can then interpolate in this table. During the elaboration of the shading table, the points (sun's positions) situated behind the plane of the PV field appear in lower height and azimuth $\pm 180^{\circ}$ until $120^{\circ}$. The perspective of PV system is placed in surrounded by a variety of building blocks that result in the shadow around the PV area.

\section{Conclusion}

Simulation result the existing data has power maximum at $\mathrm{S}_{\mathrm{TC}} 1008$ Watt with operating voltage $\left(V_{m p}\right) 18$ Volts, an open circuit voltage $\left(V_{O C}\right)$ is $223.6 \mathrm{~V}$ with voltage for 10 solar panels of $180 \mathrm{~V}$ in series. Generally, silicone crystalline type modules have -0.4 to $0.5 \% /{ }^{\circ} \mathrm{C}$ so the result of the simulation of the efficiency per cell area is $14.56 \%\left(6.880 \mathrm{~m}^{2}\right)$ and per module area is $0.15 \%\left(0.68 \mathrm{~m}^{2}\right)$ under partial shade. Shading analysis performed on each cell, these specifications in one panel consisting of 36 cells tested with Irradiance $1 \mathrm{~kW} / \mathrm{m}^{2}$ and $T_{c} 25^{\circ} \mathrm{C}$. The other parameters, the losses is about $20.8 \%$, the $P_{m p p}$ value will decrease to 792 Watt of nominal power. The maximum performance of solar panels at an angle of $18^{\circ}$ is 1.001 kilo Watt peak as desired.

\section{References}

1. A. Sangwongwanich, Mas. Thes. 11, (2014)

2. H. R. Iskandar, A. Purwadi, A. Rizqiawan, N. Heryana, ICPERE. 3, 171 (2016)

3. M. F. Nayan, S. M. S. Ulah, ICGET. 3. 6 (2015)

4. H. M. Al-Masri, A. Abu-Errub, W. R. Ayyad, M. Ehsani, SPEEDAM. 902 (2016)

5. A. Hadj. Dida, M. Bhekti, ICRERA, 6, 2 (2017)

6. C. S. Chin, P. Neelakantan, H. P. Young, S. S. Yang, K. T. K. Teo CICSyN, 7 (2011)

7. Aravinda, Padmavathi, ISPACE, 1 (2017)

8. P. Bharadwaj, A. John, 4407 (2017)

9. D. Passias, B. Kalbak. Sol. Cell. 11, 282 (1984)

10. P. Srinivasa Rao, G. S. IIango, C. Nagamani, IEEE J. of Photovoltaic. 4, 680 (2014)

11. S. Kumar, A. Selvakumar, Int. Conf. Innov. Power. Adv. Comput. Tech. 5 (2017)

12. A. Karina, S. Satwiko, Pertemuan Ilmiah XXV HFI Jateng \& DIY, 163 (2012)

13. H. R. Iskandar, A. Purwadi, A. Rizqiawan, N. Heryana, SENKA. 1 (2015)

14. A. Mermoud, Mod. Syst. Loses. In PVsyst. 15 (2010) 